
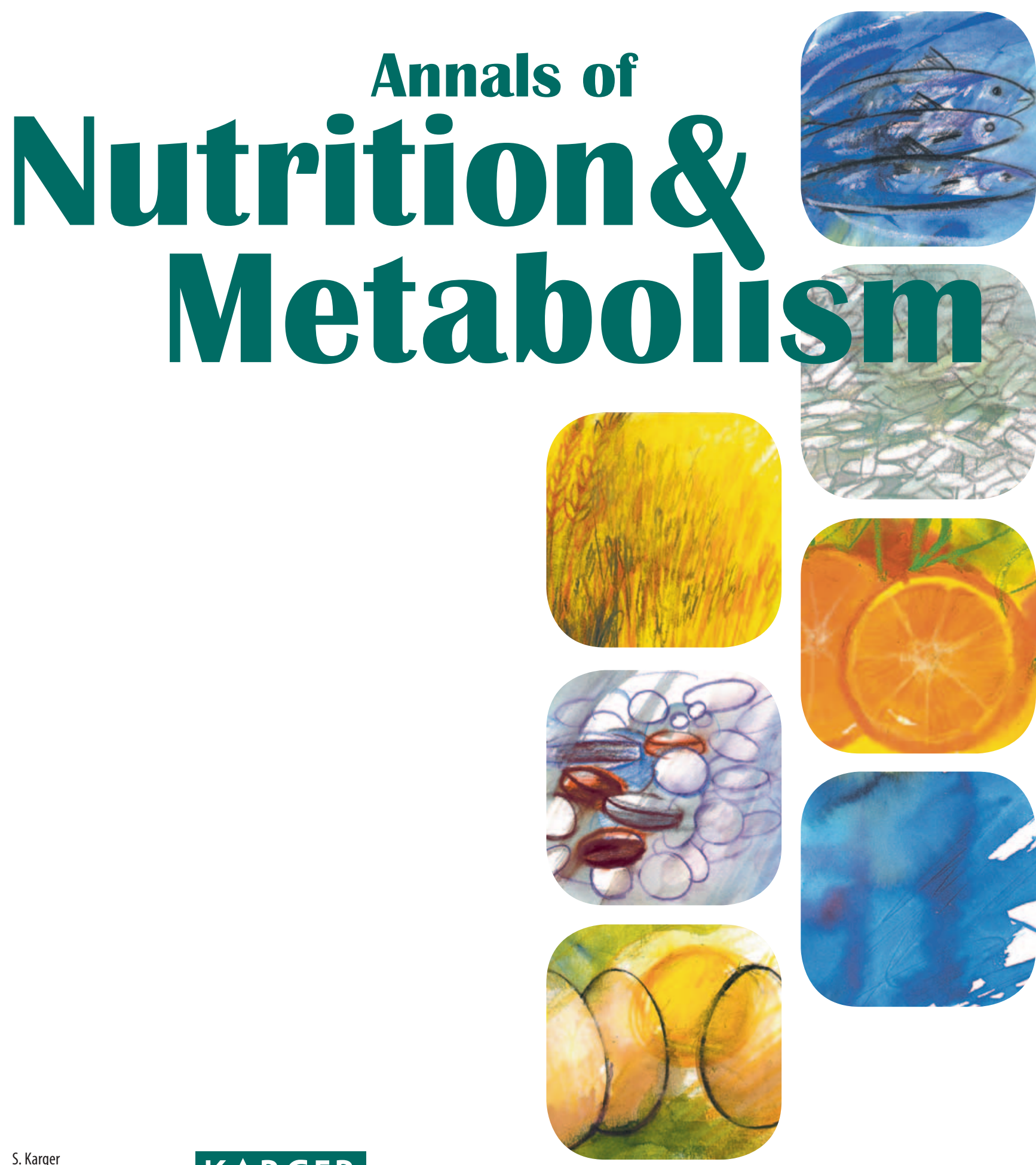


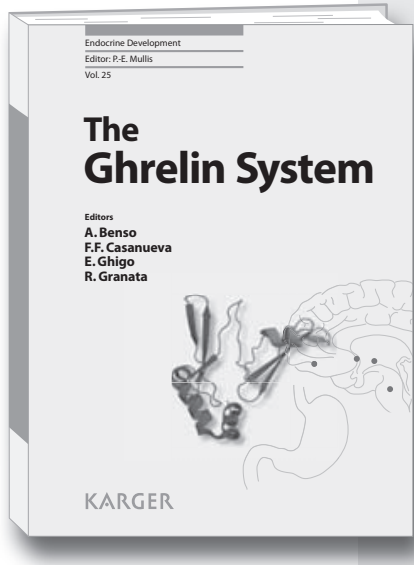

\title{
The Ghrelin System
}

\author{
Editors \\ Andrea Benso \\ Felipe Casanueva \\ Ezio Ghigo \\ Riccarda Granata
}

The Ghrelin System

Editors: Benso, A. (Turin);

Casanueva, F.F. (Santiago de Compostela); Ghigo, E.; Granata, R. (Turin)

VIII + 172 p., 16 fig., 2 in color, 4 tab., 2013

CHF 180.- / EUR 150.- / USD 212.00 (hard cover)

CHF 216.- / EUR 180.- / USD 254.00 (online)

Online version for institutional purchase

Prices subject to change

EUR price for Germany, USD price for USA only

ISBN 978-3-8055-9908-5 (hard cover)

e-ISBN 978-3-8055-9909-2

Endocrine Development, Vol. 25

Series Editor: Mullis, P.-E. (Bern)

Listed in MEDLINE/PubMed

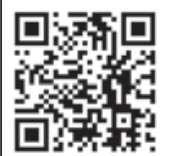

Dear Librarian

I have reviewed this publication and

would like to recommend it for our library.

Recommended by:

Department:

Date:

Signature:

Orders may be placed with any bookshop,

subscription agency, directly with the publisher

or through a Karger distributor.
The ghrelin story started more than 30 years ago with the discovery of synthetic $\mathrm{GH}$ secretagogues. Only in 1999 was ghrelin, a natural GH-releasing peptide, discovered. Ghrelin, however, is much more than simply a natural GH secretagogue. In fact, this hormone is one of the most important factors known for regulating appetite and energy expenditure. Furthermore, ghrelin is the trigger for other neuroendocrine, metabolic and nonendocrine actions.

This book, written by researchers who provided the major contributions to our current knowledge of this complex system, gives a comprehensive overview of the recent advances in ghrelin research. The hormone's influence on the cardiovascular, metabolic and gastroenteropancreatic system, hypothalamuspituitary-adrenal axis, prolactin secretion, thyroid axis, gonadal axis as well as on behavior is discussed in detail. Furthermore, the clinical perspectives for ghrelin-derived therapeutic products are presented. Illustrating the tight inter-relationship between endocrinology, metabolism, cardiovascular disease and internal medicine, this book is essential reading for all scientists interested in appetite control, body weight and energy expenditure, as well as diabetes mellitus and neuroendocrinology.

\section{Contents}

- Preface: Benso, A.; Casanueva, F.F.; Ghigo, E.; Granata, R. - Ghrelin Discovery: A Decade After: Kojima, M.; Kangawa, K.

- The Ghrelin Receptors (GHS-R1a and GHS-R1 b): Albarrán-Zeckler, R.G.; Smith, R.G.

- Discovery of Ghrelin O-Acyltransferase: Mohan, $\mathbf{H}_{\text {. }}$ Unniappan, S.

- Genetics of the Ghrelin System: Gueorguiev, M.; Korbonits, M.

- Ghrelin and the Gut: Peeters, T.L.

- Ghrelin as a GH-Releasing Factor: Carreira, M.C.; Crujeiras, A.B.; Andrade, S.; Monteiro, M.P.;

Casanueva, F.F.

- Other than Growth Hormone Neuroendocrine Actions of Ghrelin: Benso, A.; Calvi, E.; Gramaglia, E.; Olivetti, I.; Tomelini, M.; Ghigo, E.; Broglio, F.

- Ghrelin, the Gonadal Axis and the Onset of

Puberty: Tena-Sempere, $\mathbf{M}$.

- Ghrelin and the Cardiovascular System: Isgaard, J. - Ghrelin - A Key Pleiotropic Hormone-Regulating Systemic Energy Metabolism: Müller, T.D.; Tschöp, M.H.

- Ghrelin, Reward and Motivation: Menzies, J.R.W.; Skibicka, K.P.; Leng, G.; Dickson, S.L.

- Des-Acyl Ghrelin: A Metabolically Active Peptide: Delhanty, P.J.; Neggers, S.J.; van der Lely, A.J.

- Ghrelin and Tumors: Papotti, M.; Duregon, E.; Volante, M.

- Ghrelin Function in Insulin Release and Glucose Metabolism: Dezaki, $\mathbf{K}$.

- Products of the Ghrelin Gene, the Pancreatic $\beta$-Cell and the Adipocyte: Granata, R.; Ghigo, E.

- Clinical Perspectives for Ghrelin-Derived

Therapeutic Products: Allas, S.; Abribat, T.

- Author Index

- Subject Index 
An Official Journal of

International Union of Nutritional Sciences (IUNS)

\section{IUNS Editorial Representative}

I. Elmadfa, Vienna

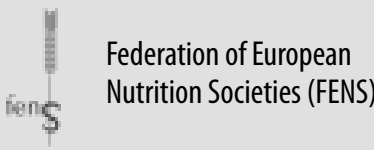

FENS Editorial Representative

D. Lairon, Marseilles

European Neutraceutical

Association (ENA)

ENA Editorial Representative

M. Lamprecht, Graz

Deutsche Gesellschaft für

Ernährung (DGE)

\section{DGE Editorial Reresentative}

H. Oberritter, Bonn

An Official Journal of

International Union of Nutritional Sciences (IUNS)

Federation of European Nutrition Societies (FENS)

European Neutraceutical Association (ENA)

Deutsche Gesellschaft für Ernährung (DGE)

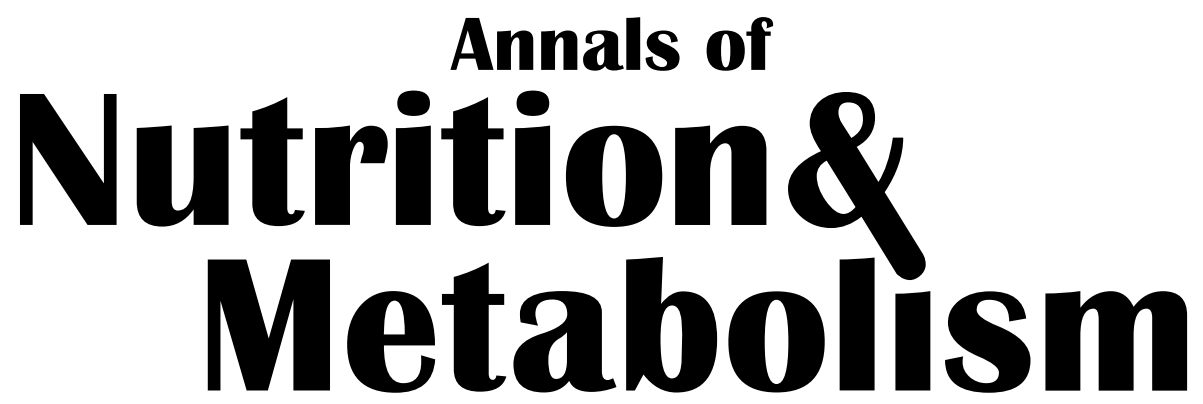

Founded 1959 as 'Nutritio et Dieta' by E. Azerad, H. Kapp and J. Trémolières. Continued by A. Wretlind (1961-1969). Continued by N. Zöllner (1970-1990) as 'Nutrition and Metabolism' (1970-1980), since 1980 integrating 'Annales de la Nutrition et de l'Alimentation', continued as 'Annals of Nutrition and Metabolism'. Continued by G. Wolfram (1991-1999), Continued by I. Elmadfa (2000-2010)

\section{Editor}

B. Koletzko, Munich

\section{Assistant Editor}

B. Kessler, Munich

\section{Associate Editors}

P.S.W. Davies, Brisbane, Qld.

L. de Groot, Wageningen

G. Desoye, Graz

A. Gil, Granada

J. Heinrich, Neuherberg

R. Meier, Liestal

S. Nagata, Tokyo

U. Nöthlings, Bonn

L. Poston, London

M.B. Zimmermann, Zurich

\section{Editorial Board}

A. Astrup, Copenhagen

A. Berg, Freiburg

Z.A. Bhutta, Karachi

S.C. Bischoff, Stuttgart

F. Branca, Rome

R. Brigelius-Flohé, Nuthetal

P.C. Calder, Southampton

S. Carlson, Kansas City, Kan.

I. Cetin, Milan

R.J. Deckelbaum, New York, N.Y.

T. Decsi, Pécs
C.J. Field, Edmonton

K. Godfrey, Southampton

R. Hakkak, Little Rock, Ark.

W.S. Harris, Sioux Falls, S. Dak.

H. Hauner, Munich

M. Hernández-Triana, Havana

H. Heseker, Paderborn

E. Hypponen, London

J. Kopecky, Prague

M. Krawinkel, Giessen

M. Lamprecht, Graz

W. Langhans, Zurich

J. Linseisen, Neuherberg

O. Ljungqvist, Örebro

J.A. Martinez, Pamplona

H.J. McArdle, Aberdeen

Y. Naito, Kyoto

P.W. Nathanielsz, San Antonio, Tex.

H. Oberritter, Bonn

R. Saffery, Parkville, Vic.

W.H.M. Saris, Maastricht

L. Serra-Majem,

Las Palmas de Gran Canaria

C. Sieber, Nürnberg

A.P. Simopoulos, Washington, D.C.

P. Singer, Petah Tikva

N.W. Solomons, Guatemala City

P. Stehle, Bonn

I. Thorsdottir, Reykjavik

K. Tontisirin, Nakhon Pathom

R. Uauy, Santiago

S. Villalpando, Cuernavaca Morelos

T. Yoshikawa, Kyoto

A. Zittermann, Bad Oeynhausen
Printed in Switzerland on acid-free and non-aging paper (ISO 9706) by Reinhardt Druck, Basel
Appears every 6 weeks: 2 volumes per year (8 issues) 


\section{ADS - ADEA ASM 2013}

Australian Diabetes Society \&

Australian Diabetes Educators Association

\section{8th - 30th August 2013 \\ Sydney Convention and Exhibition Centre}
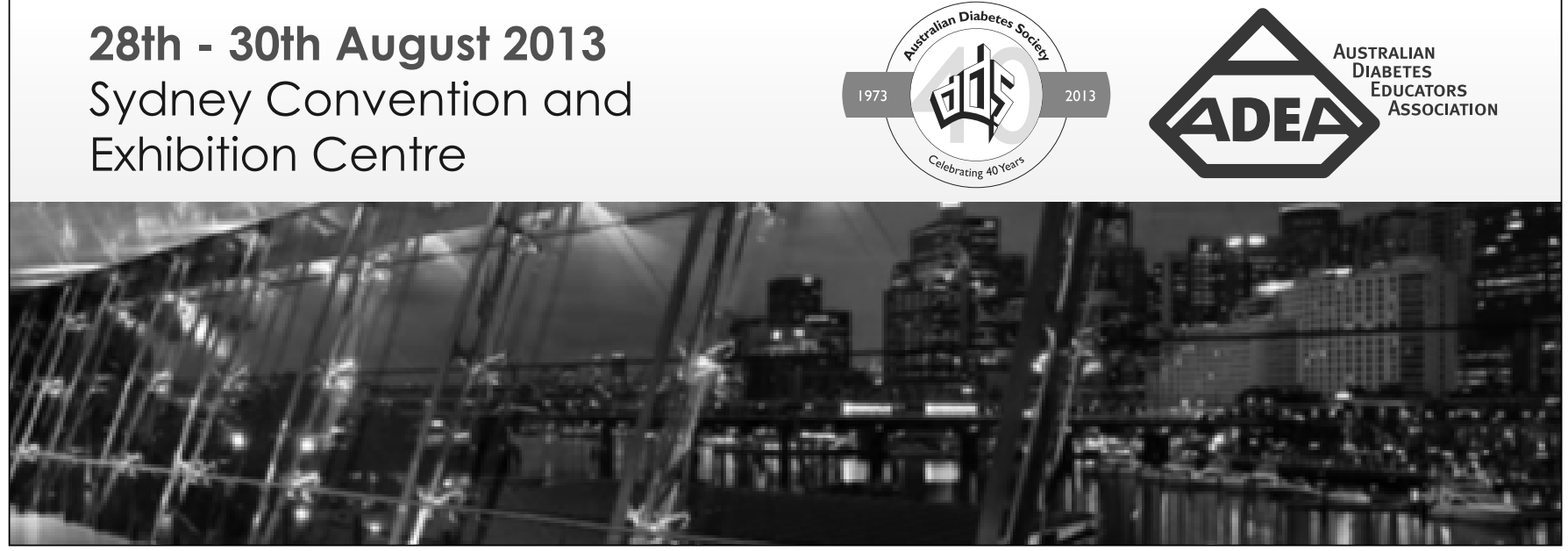

F13560

\section{Transforming Vesalius}

The medical revolution of the 16th century brought to life for the 21st century

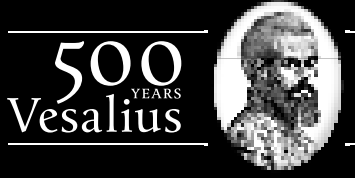

KARGER

Medical \& Scientific

Publishers

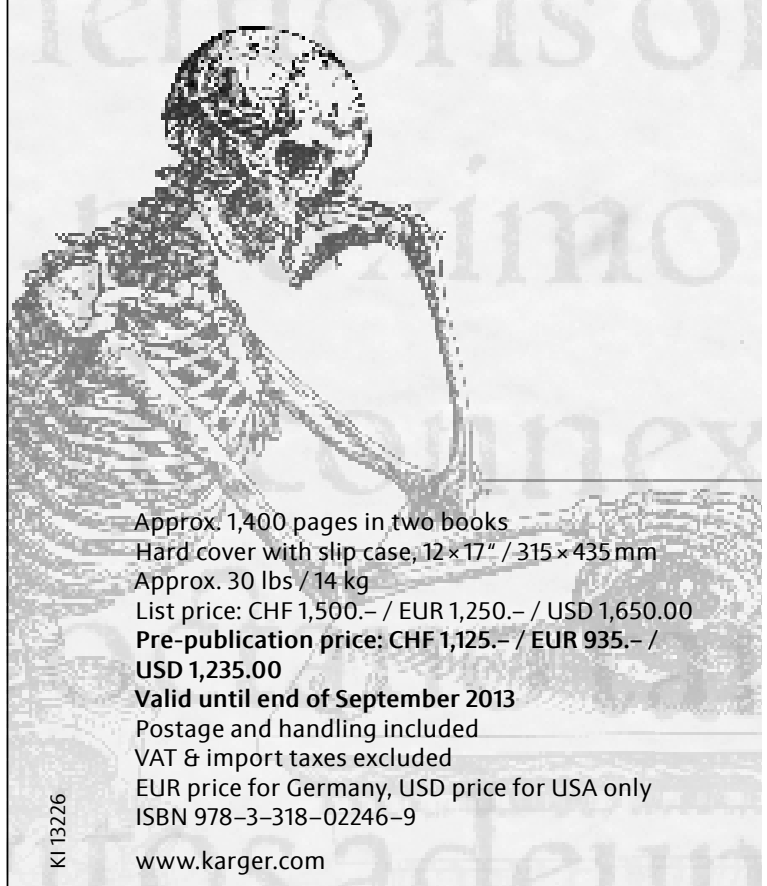

ANDREAS VESALIUS

The Fabric

\section{of the Human Body}

An Annotated Translation of the 1543 and 1555 Editions of "De Humani Corporis Fabrica" by

DANIEL H. GARRISON

MALCOLM H. HAST

- Modern layout enables the 21st-century reader to understand the complexity and pioneering nature of this milestone in medical history without the need of knowing Latin

- Added notes for a never published third edition

- Up-to-date design and high-resolution digital scans of the woodcuts

www.vesalius-fabrica.com 


\section{Contents}

Original Papers

183 Metabolic Syndrome and Central Fat Distribution Are Related to Lower Serum Osteocalcin Concentrations Bezerra dos Santos Magalhães, K.; Moreira Magalhães, M.; Trovão Diniz, E.; Salgado Lucena, C.; Griz, L.; Bandeira, F. (Recife)

189 Nutritional and Pubertal Status Influences Accuracy of Self-Reported Weight and Height in Adolescents: The HELENA Study

Béghin, L. (Lille); Huybrechts, I. (Ghent); Ortega, F.B. (Huddinge); Coopman, S. (Lille); Manios, Y. (Athens); Wijnhoven, T.M.A. (Copenhagen); Duhamel, A. (Lille); Ciarapica, D. (Rome); Gilbert, C.C. (Chipping Campden); Kafatos, A. (Heraklion); Widhalm, K. (Vienna); Molnar, D. (Pecs); Moreno, L.A. (Zaragoza); Gottrand, F. (Lille); and the HELENA study group

201 Nutritional Status Assessment of Institutionalized Elderly in Prague, Czech Republic

Rambousková, J.; Slavíková, M.; Krsková, A.; Procházka, B.; Anděl, M.; Dlouhý, P. (Prague)

207 Home Artificial Nutrition in Switzerland: An Epidemiological Survey from 2005 to 2009 Shaw, S.A.; Rühlin, M. (Winterthur); Wagener, N. (Solothurn); Stanga, Z. (Bern); Meier, R. (Liestal); Ballmer, P.E. (Winterthur)

214 Defatted Milk Is Preferred by Mexican School-Age Children over Whole Milk in a Sensorial Study

Lara-Zamudio, Y.; Villalpando, S.; Shamah-Levy, T.;

Mundo-Rosas, V.; Contreras-Manzano, A.; Lamadrid-Figueroa, H. (Cuernavaca)

223 A Weight Loss Diet Intervention Has a Similar Beneficial Effect on Both Metabolically Abnormal Obese and Metabolically Healthy but Obese Premenopausal Women

Ruiz, J.R.; Ortega, F.B. (Granada/Huddinge); Labayen, I. (Vitoria)
231 Prevalence and Determinants of Micronutrient Deficiencies among Rural Children of Eight States in India

Laxmaiah, A.; Arlappa, N.; Balakrishna, N.; Mallikarjuna Rao, K.; Galreddy, C.; Kumar, S.; Ravindranath, M.; Brahmam, G.N.V. (Hyderabad)

242 Effects of Trans-Fatty Acids on Liver Lipid Metabolism in Mice Fed on Diets Showing Different Fatty Acid Composition

Saín, J.; González, M.A. (Santa Fe); Lasa, A. (Vitoria); Scalerandi, M.V.; Bernal, C.A. (Santa Fe); Portillo, M.P. (Vitoria)

250 Long-Term Statin Administration to Dams on High-Fat Diet Protects Not Only Them but Also Their Offspring from Cardiovascular Risk

Elahi, M.M.; Cagampang, F.R.; Ohri, S.K.; Hanson, M.A. (Southampton)

257 First Report on Path Analysis for Cardiometabolic Components in a Nationally Representative Sample of Pediatric Population in the Middle East and North Africa (MENA): The CASPIAN-III Study

Kelishadi, R. (Isfahan); Motlagh, M.E. (Ahvaz/Tehran); Roomizadeh, P.; Abtahi, S.-H. (Isfahan); Qorbani, M.

(Karaj/Tehran); Taslimi, M.; Heshmat, R.; Aminaee, T. (Tehran); Ardalan, G. (Isfahan/Tehran); Poursafa, P. (Isfahan); Karimi, M. (Karaj)

266 FENS News

267 IUNS News

269 ENA News

\section{KARGER}

E-Mail karger@karger.com www.karger.com
๑) 2013 S. Karger AG, Basel

Access to full text and tables of contents, including tentative ones for forthcoming issues: www.karger.com/anm_issues 


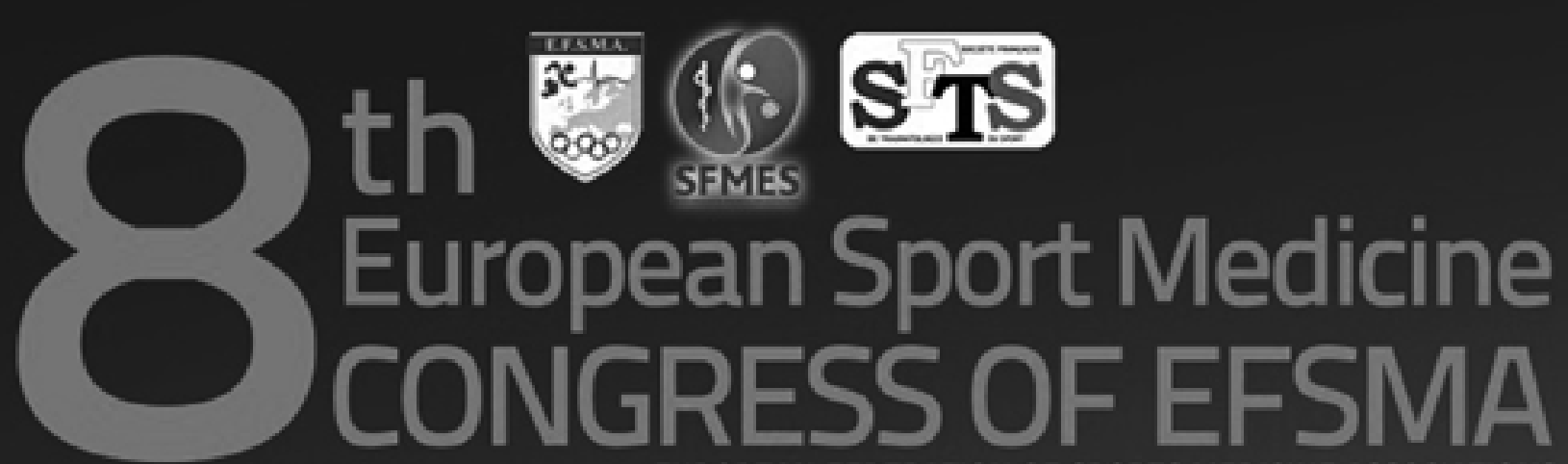
EUROPEAN FEDERATION OF SPORTS MEDICINE ASSOCIATIONS
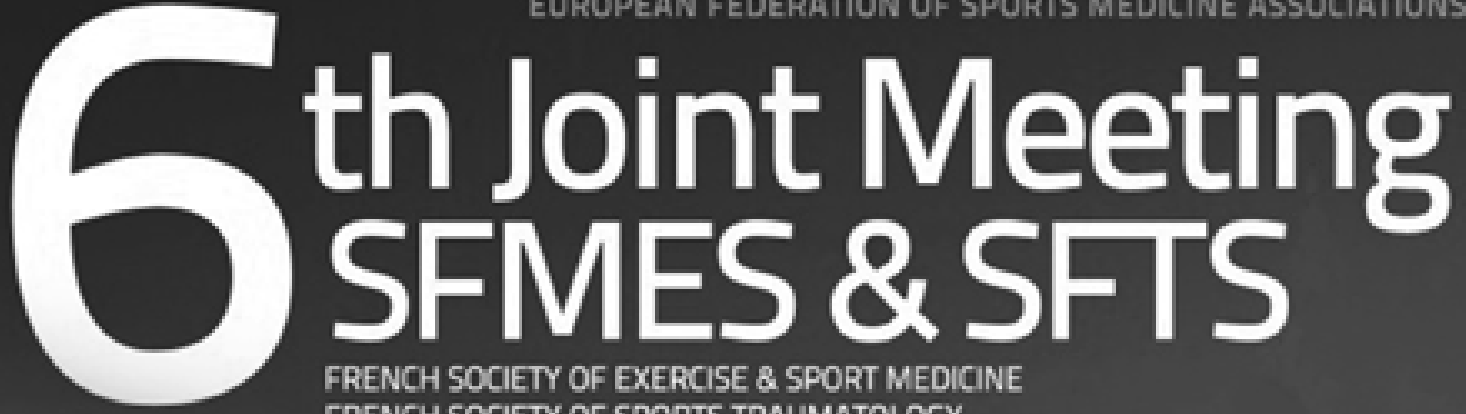

FRENCH SOCIETY OF EXERCISE \& SPORT MEDICINE

FRENCH SOCIETY OF SPORTS TRAUMATOLOGY

Deadline for abstract submission: June 3, 2013

Abstract submission, Programme, Registration, Acommodation: www.efsma-strasbourg2013.fr

Sessions:

- Exercise Prescription for Health

- Sports Medicine Specialty in Europe

- Pain Management in Sports

- Ethics in Sports Medicine

- Health Problems of Nutritional Supplements

- Football Medicine

- Fatigue and Recovery

- Molecular Medicine in Sports and Exercise

- Physical Activity for Elderly

- Physical Activity and Type 1 and Type 2 Diabetes

- Emergency Care in Sport

- Injury Prevention in Sport

- Imaging in Sports Medicine

- Tendinopathy

- Botulinum Toxin Therapy in Sports Medicine

- Prevention of ACL injury

- Sport in Children

- Military Medicine (carrying heavy loads and physical problems)

- Focal Lesions of the Athlete Knee

- FIMS - IOC and International Federations of Sports

- New Trends in Muscle Injuries

- Antidoping Strategies in Europe (Council of Europe, WADA, Sports Ministery-AFLD-CNOSF)

- Hip Arthroplasty Resurfacing in Young Athletes 


\section{Nutrinals of Metabolism}

ISSN Print Edition: 0250-6807 ISSN Online Edition: 1421-9697

Journal Homepage: www.karger.com/anm

Publication Data: 'Annals of Nutrition and Metabolism' is published 8 times a year. Volumes 62 and 63, each with 4 issues, appear in 2013.

Copyright: (c) 2013 S. Karger AG, Basel (Switzerland). All rights reserved. No part of this publication may be translated into other languages, reproduced or utilized in any form or by any means, electronic or mechanical, including photocopying, recording, microcopying, or by any information storage and retrieval system, without permission in writing from the publisher or, in the case of photocopying, direct payment of a specified fee to the Copyright Clearance Center.

Disclaimer: The statements, opinions and data contained in this publication are solely those of the individual authors and contributors and not of the publisher and the editor(s). The appearance of advertisements in the journal is not a warranty, endorsement, or approval of the products or services advertised or of their effectiveness, quality or safety. The publisher and the editor(s) disclaim responsibility for any injury to persons or property resulting from any ideas, methods, instructions or products referred to in the content or advertisements.
Subscription Rates: Subscriptions run for a full calendar year. Prices are given per year. Personal subscription:

Print or Online

CHF 1019.-

EUR 822.-

USD 1009.00

Print+Online combined CHF 1115.-

EUR 900.-

USD 1105.00

postage and handling (added to print and print+online)

CHF 57.60 Europe, CHF 83.20 Overseas

EUR 44.80

USD 76.80

Institutional subscription:

Print or Online

Print+Online combined

CHF 3398.-

EUR 2740.-

CHF 3738.-

postage and handling (added to print and print+online)

CHF 72.- Europe, CHF 104.- Overseas

EUR 56.-

USD 96.00

Airmail surcharge: CHF 70.- / USD 66.00

Discount subscription prices:

Please enquire about reduced rates for members of affiliated societies.
Back Volumes and Single Issues: Information on availability and prices of single print issues and print or electronic back volumes can be obtained from Customer Service atservice@karger.com.

Bibliographic Indices: This journal is regularly listed in bibliographic services, including Current Contents ${ }^{\circledR}$ and PubMed/MEDLINE.

Photocopying: This journal has been registered with the Copyright Clearance Center (CCC), as indicated by the code appearing on the first page of each article. For readers in the US, this code signals consent for copying of articles for personal or internal use, or for the personal or internal use of specific clients, provided that the stated fee is paid per copy directly to

Copyright Clearance Center Inc.

222 Rosewood Drive

Danvers, MA 01923 (USA)

A copy of the first page of the article must accompany payment. Consent does not extend to copying for general distribution, for promotion, for creating new works, or for resale. In these cases, specific written permission must be obtained from the copyright owner,

S. Karger AG, P.O. Box

CH-4009 Basel (Switzerland).

\begin{tabular}{|c|c|c|}
\hline $\begin{array}{l}\text { Subscription Orders: } \\
\text { Orders can be placed at agencies, } \\
\text { bookstores, directly with the Publisher }\end{array}$ & $\begin{array}{l}\text { or further Karger offices } \\
\text { or representatives: }\end{array}$ & $\begin{array}{l}\text { USA } \\
\text { S. Karger Publishers, Inc. } \\
26 \text { West Avon Road }\end{array}$ \\
\hline & Germany & P.O. Box 529 \\
\hline S. Karger AG & S. Karger GmbH & Unionville, CT 06085 \\
\hline Medical and Scientific Publishers & Postfach & USA \\
\hline Allschwilerstrasse 10 & 79095 Freiburg & Toll free: +18008285479 \\
\hline CH-4009 Basel & Deutschland & $\mathrm{t}: \quad+18606757834$ \\
\hline Switzerland & $\begin{array}{l}\text { (Hausadresse: Wilhelmstrasse 20A, } \\
79098 \text { Freiburg) }\end{array}$ & $\begin{array}{l}\text { f: }+18606757302 \\
\text { e: karger@snet.net }\end{array}$ \\
\hline t: +41613061111 & $\mathrm{t}: \quad+49761452070$ & \\
\hline f: +41613061234 & f: $\quad+497614520714$ & France \\
\hline e: karger@karger.com & e: information@karger.de & Librairie Médi-Sciences Sarl \\
\hline w: www.karger.com & w: www.karger.de & $\begin{array}{l}\text { 36, bd de Latour-Maubourg } \\
75007 \text { Paris }\end{array}$ \\
\hline (for courier services only: & Japan & France \\
\hline Allschwilerstrasse 10 & Karger Japan, Inc. & $\mathrm{t}: \quad+33(0) 145514258$ \\
\hline CH-4055 Basel) & Shiba Daimon Asahi Bldg. 2F & $\mathrm{f}: \quad+33(0) 145560780$ \\
\hline & 1-2-23 Shiba Daimon & e: librairie@medi-sciences.fr \\
\hline & Minato-ku & w: www.medi-sciences.fr \\
\hline & Tokyo 105-0012 & \\
\hline & Japan & \\
\hline & $\begin{array}{l}\text { t: }+81364356242 \\
f:+81364356244\end{array}$ & \\
\hline & e: publisher@karger.jp & \\
\hline & w: www.karger.jp & \\
\hline
\end{tabular}

Change of Address:

Both old and new address should be sent

to the subscription source.

\section{KARGER}

E-Mail karger@karger.com www.karger.com
(C) 2013 S. Karger AG, Basel

The Journal Home Page is available at:

www.karger.com/anm
South East Asia, China and Taiwan Karger Regional Office (Malaysia)

CEO Suite Kuala Lumpur

Quill 7, 27th Floor

Jalan Stesen Sentral 5

KL Sentral

Kuala Lumpur 50470

Malaysia

t: +60327766803

f: +60327766999

e: service@karger.cn; r.chew@karger.cn

Karger China

10th Floor, Twin Towers (East)

B12 Jianguomenwai Avenue

Beijing 100022

China

$\mathrm{t}:+861051235033$

f: +861051235122

e: service@karger.cn; r.chew@karger.cn

w: www.karger.cn

India, Bangladesh, Sri Lanka

Medscience India

Plot No. 17, Yusuf Sarai Market

B.L. Glass Building, 2nd Floor

Sri Aurobindo Marg

New Delhi 110016

India

t: +911146029633

f: +911146029634

c: +919891052128

e: medsci.india@gmail.com 


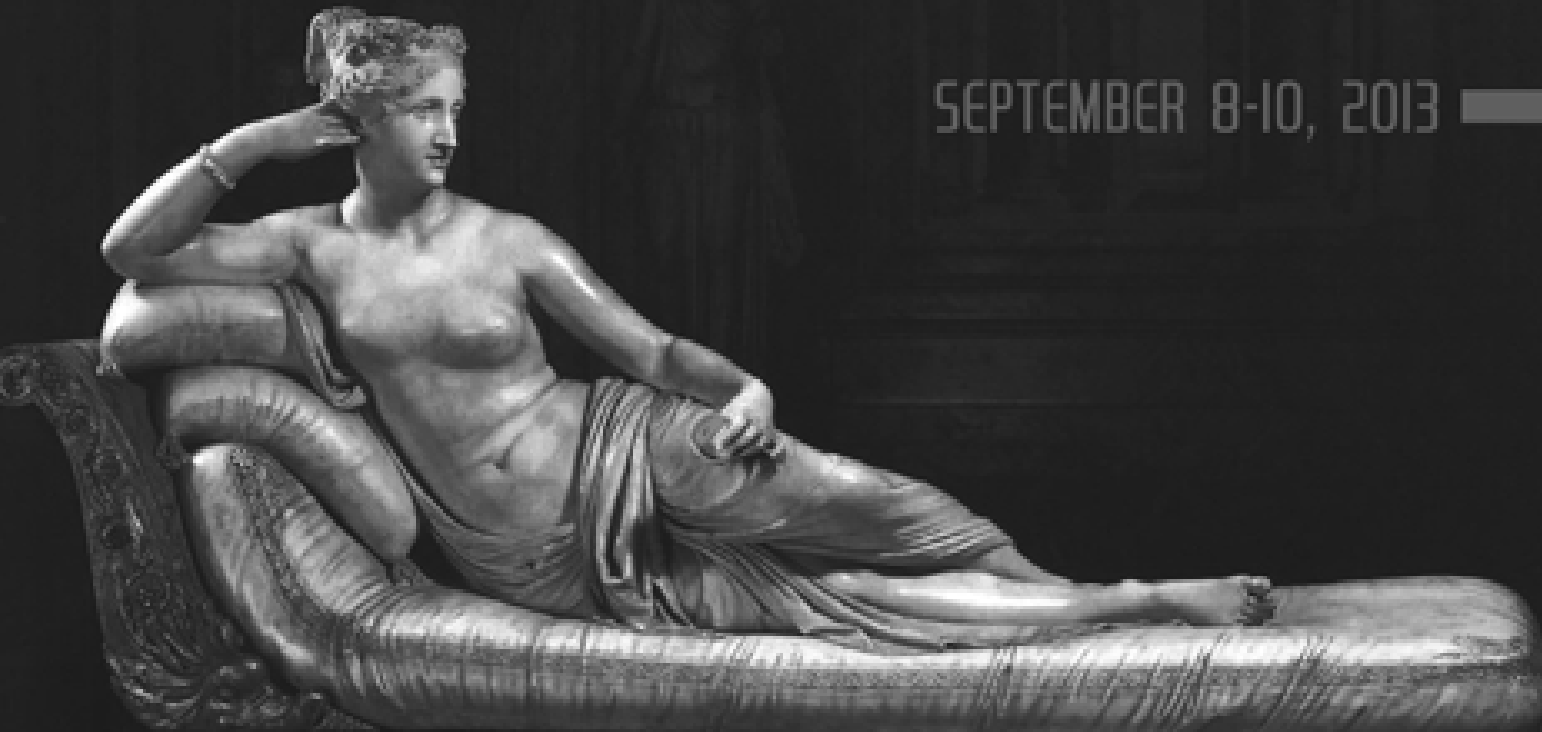

\section{$7^{\text {TH PROBIOTICS PREB|OTICS }}$}

\section{new foods}

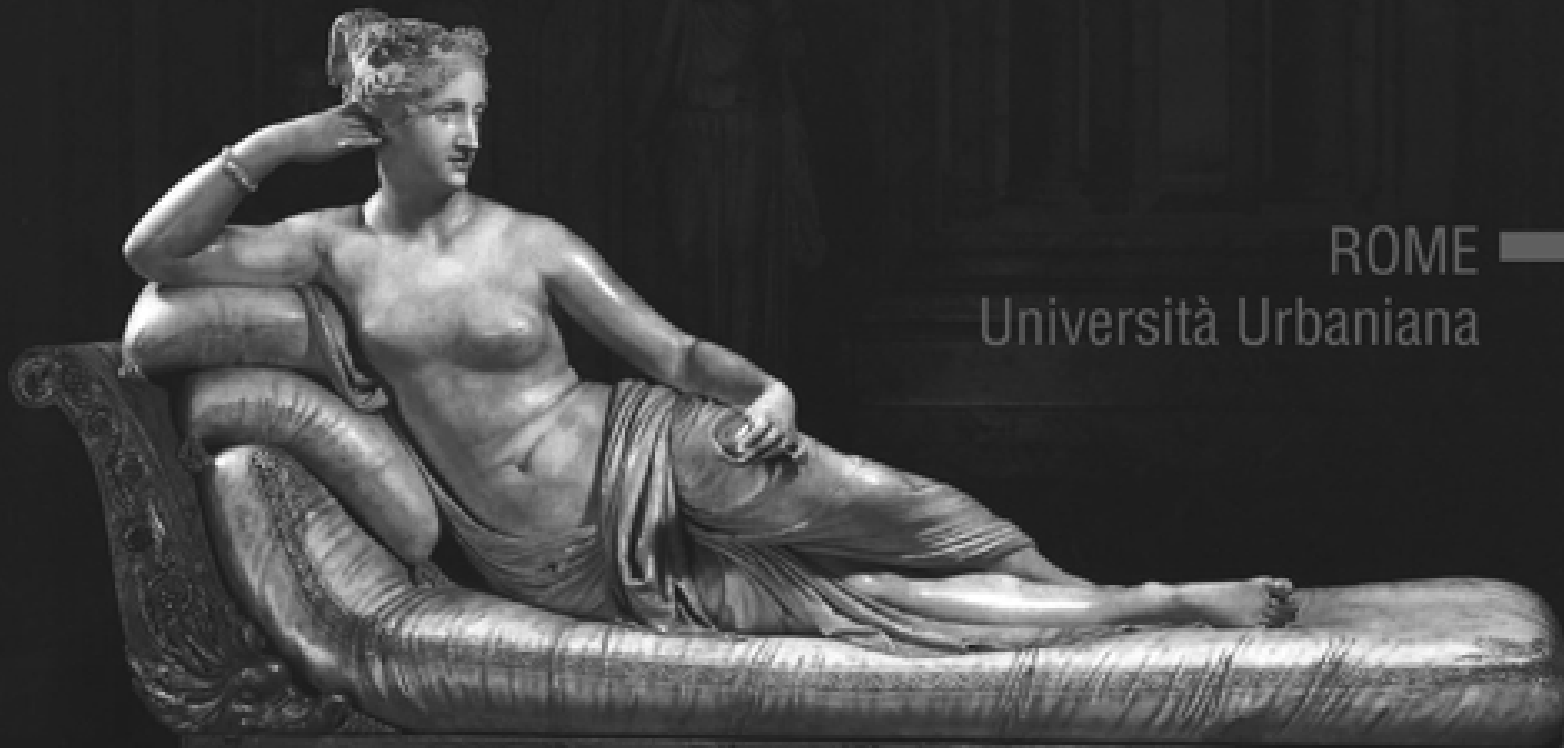

www.probiotics-prebiotics-newfood.org 


\section{Contents}

See the journal website for contents

KARGER Basel $\bullet$ Freiburg $\cdot$ Paris $\bullet$ London $\bullet$ New York $\cdot$ New Delhi $•$ Bangkok Beijing $\cdot$ Tokyo $\cdot$ Kuala Lumpur $\cdot$ Singapore $\bullet$ Sydney 


\section{Nutritional of Metabolism}

\section{Aims and Scope}

The journal focuses on human nutrition and metabolism and related areas, including experimental studies and basic science that can inform human nutrition science. We welcome manuscripts describing observational and intervention studies as well as basic science reports on the topics of foods, diets and dietary supplements, nutrigenomics and genetics related to metabolism, on energy metabolism, macro- and micronutrients including vitamins and minerals, biofunctional compounds, dietetics, obesity, clinical nutrition social sciences and health economy as related to nutrition and metabolism and nutrition policy. Laboratorybased science may include descriptions of relevant experimental models. In addition to Original Papers, the journal will publish Review Articles on topical subjects, Systematic Reviews, short Commentaries and Viewpoint articles that may address current controversies, short Meeting Reports, Letters to the Editor, and Announcements/Society News. The journal will also publish Supplements with proceedings from internationally relevant conferences on nutrition and metabolism.

\section{Submission}

Manuscripts written in English are considered and should be submitted online at

\section{www.karger.com/anm}

Authors may suggest up to four Referees who have expert knowledge on the subject. Suggested Referees should not be from the same institution, not have published with the authors during the last 5 years, and should not be prejudiced.

Should you experience problems with your submission, please contact
Prof. Dr. B. Koletzko
Div. Metabolic and Nutritional Medicine
Dr. von Hauner Children's Hospital
Ludwig-Maximilians-University of Munich
Lindwurmstrasse 4
D-80337 Munich (Germany)
Tel. +498951602826
E-Mail ANM@med.uni-muenchen.de

\section{Conditions}

All manuscripts are subject to editorial review. Manuscripts are received with the explicit understanding that they are not under simultaneous consideration by any other publication. Submission of an article for publication implies transfer of the copyright from the author to the publisher upon acceptance. Accepted papers become the permanent property of Annals of Nutrition and Metabolism and may not be reproduced by any means, in whole or in part, without the written consent of the publisher. It is the author's responsibility to obtain permission to reproduce illustrations, tables, etc. from other publications.

\section{Types of Articles}

The journal consists of the following sections:

Original Papers are full-length research papers which will be considered for the journal. Articles cover topics relevant to clinical studies. Basic and experimenta work appear only if directly related to clinical issues (max. 2,500 words)

Review Articles/Systematic Reviews in which a specific field is reviewed through an exhaustive literature survey. An Abstract is required and should be divided into
Background, Summary and Key Messages. Review Articles should consist of a maximum of 4,000 words.

Commentaries and Viewpoint of an editorial nature may be submitted to the journal. In these communications, usual manuscript subdivisions do not apply, and a summary statement is not needed; however, a very brief reference list may be included (max. 500 words).

Meeting Reports are brief summaries of scientific meetings in the field of nutrition and metabolism. Authors should write a letter to the Editors inquiring about potential interest before submitting the paper $(\max .1,500$ words).

Letters to the Editor are encouraged if they directly concern articles previously published in this journal or clinical subjects related to the matters discussed. The editor reserves the right to submit copies of such letters to the authors of the articles concerned prior to publication in order to permit them to respond in the same issue of the journal (max. 500 words).

Editorials are usually invited by the Editor (max. 1,000 words). Please send suggestions to the Editor.

Authors are referred to the uniform requirements for manuscripts submitted to biomedical journals (http://www.icmje.org/ethical_lauthor.html) for further guidance.

\section{Conflicts of Interest}

Authors are required to disclose any sponsorship or funding arrangements relating to their research and all authors should disclose any possible conflicts of interest. Conflict of interest statements will be published at the end of the article.

\section{Ethics}

Published research must comply with the guidelines for human studies and animal welfare regulations. Authors should state that subjects have given their informed consent and that the study protocol has been approved by the institute's committee on human research. Further, they should also state that animal experiments conform to institutional standards.

\section{Plagiarism Policy}

Plagiarism is misrepresenting somebody else's published intellectual work-product as your own (Note, this definition excludes 'self-plagiarism'). In short, it is a misuse of source material. Whether intentional or unintentional, plagiarism is a serious violation of the Annals of Nutrition and Metabolism policy. Periodically, manuscripts are screened for plagiarism and if your manuscript is found to be consistent with what the Editors define $e^{\star}$ as plagiarism prior to review of the manuscript then

- it will be rejected without review and the author(s) notified as such with a chance for rebuttal.

If a manuscript is found to contain evidence of plagiarism after acceptance and/or publication then

- the author(s) will be notified, as in the previous situation, and offered a chance for rebutta.

If the rebuttal arguments are not found to be satisfactory, as judged by the Editors, the manuscript will be rejected and the author sanctioned from publishing additional papers in the Journal for a period to be determined by the Editorial Board. The period of sanction imposed is dependent on the magnitude of plagiarism with a minimum sanction of one year.
If a manuscript already published in the Journal is found to exhibit evidence of plagiarism as defined by the Editors ${ }^{*}$, then we will request a retraction.

${ }^{\star}$ Definition of plagiarism - a $25 \%$ similarity in the Results or Discussion that exactly reproduces another paper.

\section{Arrangement}

Title page: The first page of each paper should indicate the title, the authors' names, the institute where the work was conducted, and a short title for use as running head.

Full address: The exact postal address of the corresponding author complete with postal code must be given at the bottom of the title page. Please also supply phone and fax numbers, as well as e-mail address.

Key words: For indexing purposes, a list of 3-10 key words in English is essential.

Abstracts of Reviews: Should be divided into the following subsections: Background, Summary and Key Messages. The Background should provide a brief clinical context for the review and is followed by the Summary, which should include a concise description of the main topics covered in the text. The Key Messages encapsulate the main conclusions of the review.

Abstract: Each paper needs an abstract of up to 200 words. It should be structured as follows:

Background/Aims: What is the major problem that prompted the study?

Methods: $\quad$ How was the study performed?

Results: Most important findings?

Conclusion: Most important conclusion?

Footnotes: Avoid footnotes.

Tables and illustrations: Tables are part of the text. Place them at the end of the text file. Illustration data must be stored as separate files. Do not integrate figures into the text. Electronically submitted $\mathrm{b} / \mathrm{w}$ half-tone and color illustrations must have a final resolution of $300 \mathrm{dpi}$ after scaling, line drawings one of $800-1,200 \mathrm{dpi}$.

\section{Color illustrations}

Online edition: Color illustrations are reproduced free of charge. In the print version, the illustrations are reproduced in black and white. Please avoid referring to the colors in the text and figure legends.

Print edition: Up to 6 color illustrations per page can be integrated within the text at CHF 800.- per page.

References: In the text, identify references by Arabic numerals [in square brackets]. Material submitted for publication but not yet accepted should be noted as [unpublished data] and not be included in the reference list. The list of references should include only those publications which are cited in the text. Do not alphabetize; number references in the order in which they are first mentioned in the text. The surnames of the authors followed by initials should be given. There should be no punctuation other than a comma to separate the authors. Preferably, please cite all authors. Abbreviate journal names according to the Index Medicus system. Also see International Committee of Medical Journal Editors: Uniform requirements for manuscripts submitted to biomedical journals (www.icmje.org).

Examples

(a) Papers published in periodicals: Chatel J-M, Bernard $\mathrm{H}$, Orson FM: Isolation and characterization of two complete Ara h 2 isoforms cDNA. Int Arch Allergy Immunol 2003;131:14-18.

\section{KARGER}

E-Mail karger@karger.com www.karger.com
(C) 2013 S. Karger AG, Basel 


\section{Guidelines for Authors}

\section{Nutrition 8 Metabolism}

(b) Papers published only with DOI numbers:

Theoharides TC, Boucher W, Spear K: Serum interleukin-6 reflects disease severity and osteoporosis in mastocytosis patients. Int Arch Allergy Immunol DOI: $10.1159 / 000063858$

(c) Monographs: Matthews DE, Farewell VT: Using and Understanding Medical Statistics, ed 3, revised. Basel, Karger, 1996.

(d) Edited books: DuBois RN: Cyclooxygenase-2 and colorectal cancer; in Dannenberg AJ, Dubois RN (eds): COX-2. Prog Exp Tum Res. Basel, Karger, 2003, vol 37, pp 124-137.

Reference Management Software: Use of EndNote is recommended for easy management and formatting of citations and reference lists.

\section{Digital Object Identifier (DOI)}

S. Karger Publishers supports DOIs as unique identifiers for articles. A DOI number will be printed on the title page of each article. DOIs can be useful in the future for identifying and citing articles published online without volume or issue information. More information can be found at www.doi.org.

\section{Supplementary Material}

Supplementary material is restricted to additional data that are not necessary for the scientific integrity and conclusions of the paper. Please note that all supplementary files will undergo editorial review and should be submitted together with the original manuscript The Editors reserve the right to limit the scope and length of the supplementary material. Supplementary material must meet production quality standards for Web publication without the need for any modification or editing. In general, supplementary files should not exceed $10 \mathrm{Mb}$ in size. All figures and tables should have titles and legends and all files should be supplied separately and named clearly. Acceptable files and formats are: Word or PDF files, Excel spreadsheets (only if the data cannot be converted properly to a PDF file), and video files (.mov, .avi, .mpeg)

\section{Author's Choice ${ }^{\mathrm{TM}}$}

Karger's Author's Choice ${ }^{\mathrm{TM}}$ service broadens the reach of your article and gives all users worldwide free and full access for reading, downloading and printing at www.karger.com. The option is available for a onetime fee of CHF 3,000.-, which is a permissible cost in grant allocation. More information can be found at www.karger.com/authors_choice.

\section{NIH-Funded Research}

The U.S. National Institutes of Health (NIH) mandates under the NIH Public Access Policy that final, peer-reviewed manuscripts appear in its digital database within 12 months of the official publication date. As a service to authors, Karger submits the final version of your article on your behalf to PubMed Central. For those selecting our premium Author's Choice ${ }^{\mathrm{TM}}$ service, we will send your article immediately upon publishing, accelerating the accessibility of your work without the usual embargo. More details on NIH's Public Access Policy is available at http://publicaccess.nih.gov/FAQ.htm\#al

\section{Self-Archiving}

Karger permits authors to archive their pre-prints (i.e. pre-refereeing) or post-prints (i.e. final draft post-refereeing) on their personal or institution's servers, provided the following conditions are met: Articles may not be used for commercial purposes, must be linked to the publisher's version, and must acknowledge the publisher's copyright. Authors selecting Karger's Author's Choice ${ }^{\mathrm{TM}}$ feature, however, are also permitted to archive the final, published version of their article which includes copyediting and design improvements as well as citation links.

\section{Page Charges}

There are no page charges for papers of 3 or fewer printed pages (including tables, illustrations and references). Each additional complete or partial page is charged to the author at CHF 325.-- The allotted size of a paper is equal to approx. 10 manuscript pages (including tables, illustrations and references).

\section{Proofs}

Unless indicated otherwise, proofs are sent to the firstnamed author and should be returned with the least possible delay. Alterations made in proofs, other than the correction of printer's errors, are charged to the author.

\section{Reprints}

Order forms and a price list are sent with the proofs. Orders submitted after the issue is printed are subject to considerably higher prices.

\section{3th International Congress of the Immunology of Diabetes Society}

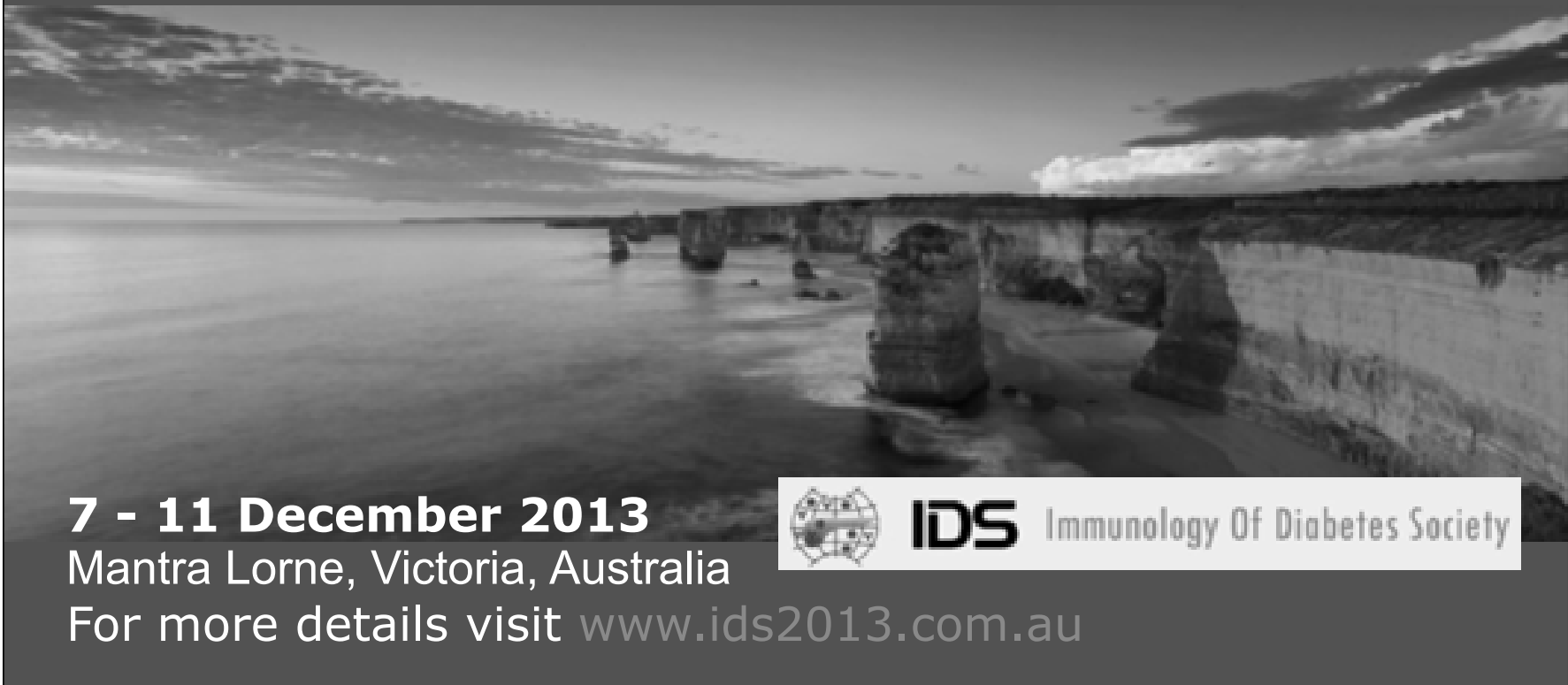

\section{KARGER}

E-Mail karger@karger.com www.karger.com
(C) 2013 S. Karger AG, Basel

The Journal Home Page is available at:

www.karger.com/anm_Guidelines 


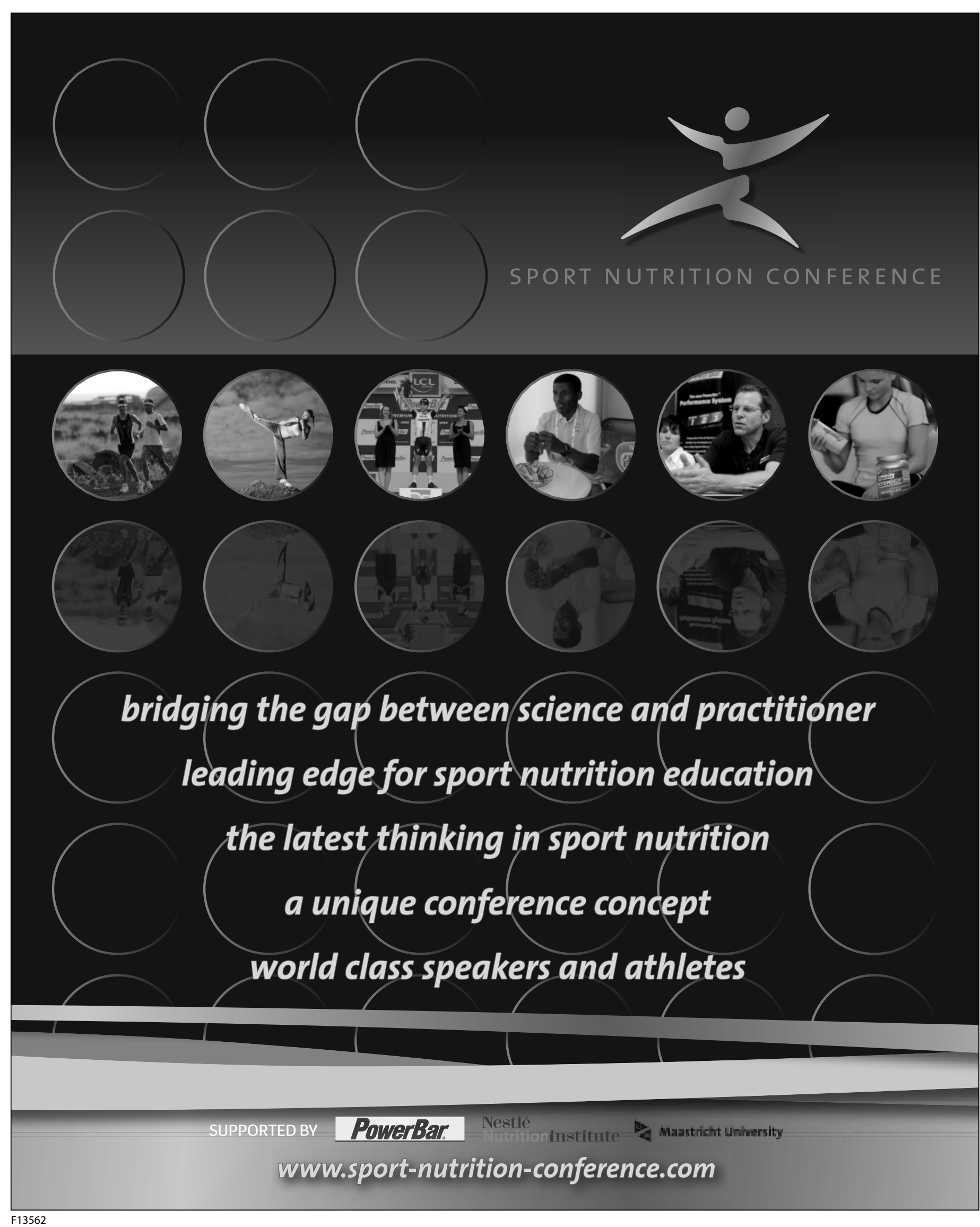




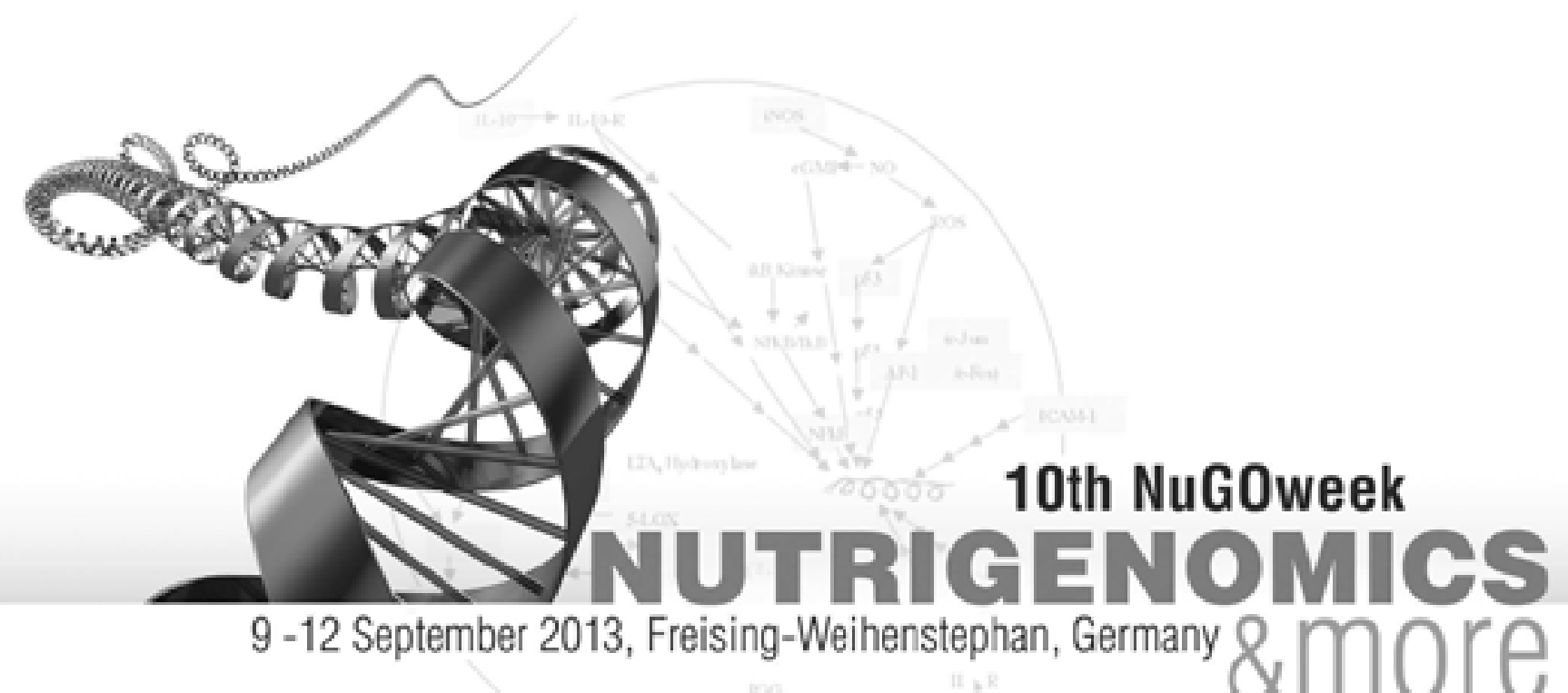

\section{Topics and Speakers}

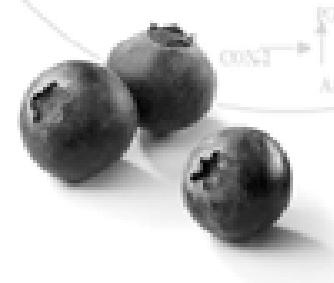

We are pleased to announce the 10th NuGOweek at the Technische Universität München in Germany

\section{Evolution \& genomes}

- Mark Stoneking, MPI Anthropology, Leipzig, Germany

- Stephen Wooding, University of Texas, Dallas, USA

\section{Genes and what we like}

- Wolfgang Meyerhof, DIfE, Germany

- Danielle Reed, Monell Chemical Senses Center, Philadelphia, USA

\section{Genes and BMI}

- Johannes Hebebrand, LVR Klinikum, Duisburg-Essen, Germany

- Martin Klingenspor, Technische Universität München, Germany

Genetics and genomics in metabolic syndrome research

- Karine Clément, Cordelier Research Centre, Paris, France

- Rui Wang Sattler, AME, Helmholtz Zentrum München, Germany

\section{Diet and genome in cancer development}

- Jane Figueiredo, Keck School of Medicine, University of Southern California, USA

- Johanna Lampe, Fred Hutchinson Cancer Research Center, Seattle, USA

Genetics and genomics in diabetes research

- Anette Ziegler, IDF, Helmholtz Zentrum München, TUM, Germany

- Annette Schürmann, DIfE, Potsdam, Germany

- Leif Groop, Lund University, Sweden
Vitamins and genetic variation

- Cornelia Ulrich, DKFZ, Heidelberg, Germany

- Andy Levy, Technicon - Israel Institute of Technology, Haifa, Israel

Biology of omega-3-fatty acids

- Rui Curi, University of São Paulo, Brasil

- Bernhard Bader, Technische Universität München, Germany

Diet responses on the background of genetic variation

- Helen Roche, University College of Dublin, Ireland

- José López-Miranda, University of Cordoba, Spain

Nutrigenomics Technologies

- Dietrich Rein, Metanomics Health, Berlin, Germany

- Martin Seifert, Genomatix Software $\mathrm{GmbH}$, München, Germany

\section{New Projects - new approaches}

- Marianne Walsh, UCD, Dublin, Ireland

- Jildau Bouwman, Netherlands Metabolomics Centre, Leiden, The Netherlands

- Jo Goosens, De Hoorn Creative Minds, Belgium

The Future of diet-health research in Europe

- Wim Saris, Maastricht University Medical Centre, The Netherlands

- Laura Alexandrescu, European Commission, Brussels, Belgium 


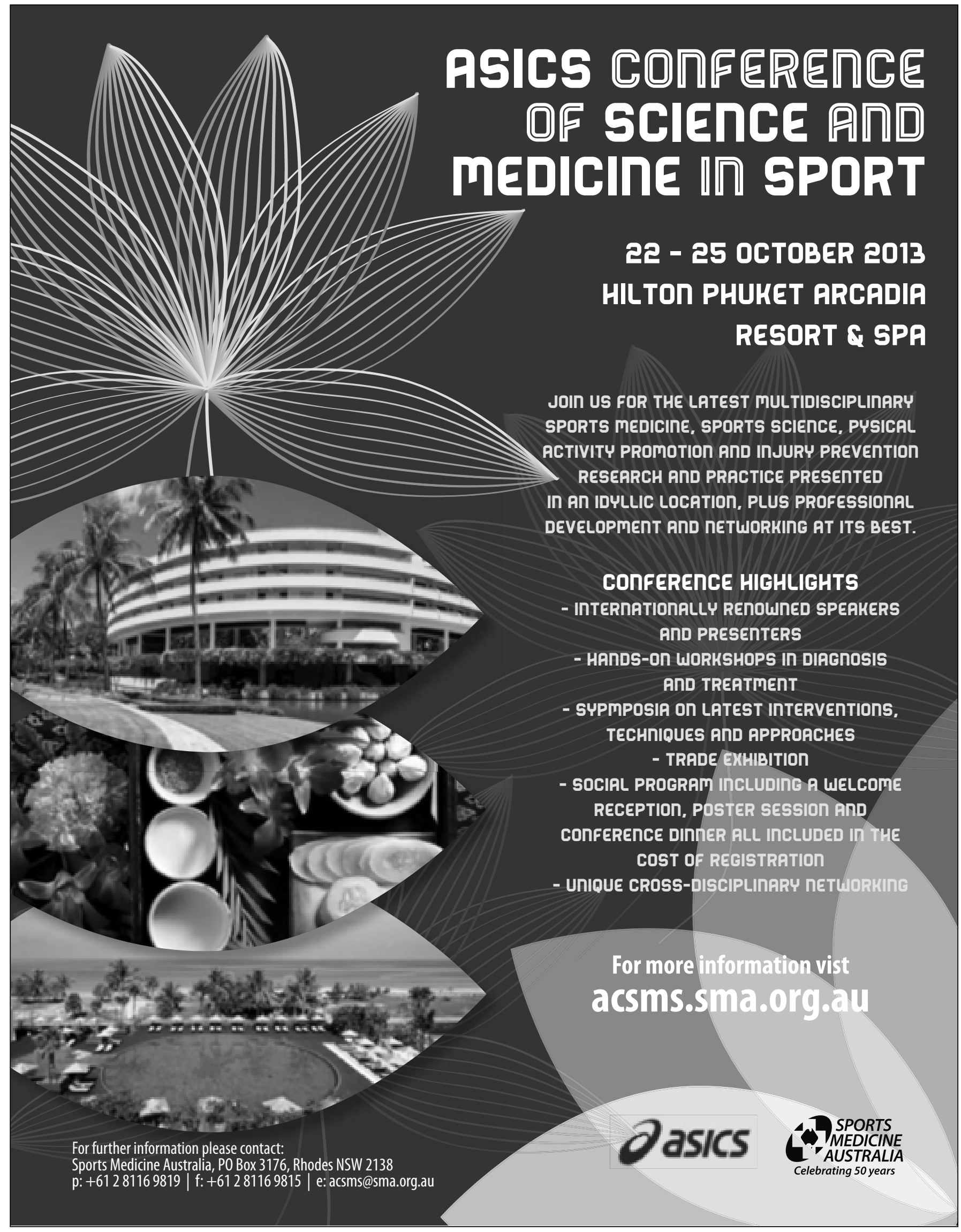




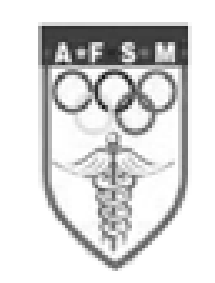

\section{3th Asian Federation of Sports Medicine Congress}

\section{5th to 28th September 2013}

Venue: Berjaya Times Square Convention Centre, Kuala Lumpur

Theme: Towards Excellence in Sports Medicine and Sports Science

\section{Introduction}

The Malaysian Association of Sports Medicine is proud to be host to the 13th AFSM Congress in Kuala Lumpur, Malaysia.

\section{Important dates}

The 13th AFSM congress will be held from 25th to 28th September 2013. Please block these dates in your diary to attend a top class International Sports Medicine and Sports Science meeting in Malaysia. All keynote and plenary speakers are expected to submit latest review papers with references which will be put into a congress DVD. Free paper, e-poster and poster presentations are also available.

\section{Register now}

Please email us at 13afsm@gmail.com which is the email for all correspondence regarding the conference. Our official website for the conference is www.13afsm.com. Please register using this website which has an online form to fill and submit. Online forms to cut and paste your review papers or abstracts for free papers, e-poster or traditional posters will also be on this website and you will get a response within two months. We invite you to come and enjoy Malaysia which is 'truly Asia'.

\section{www.13afsm.com}
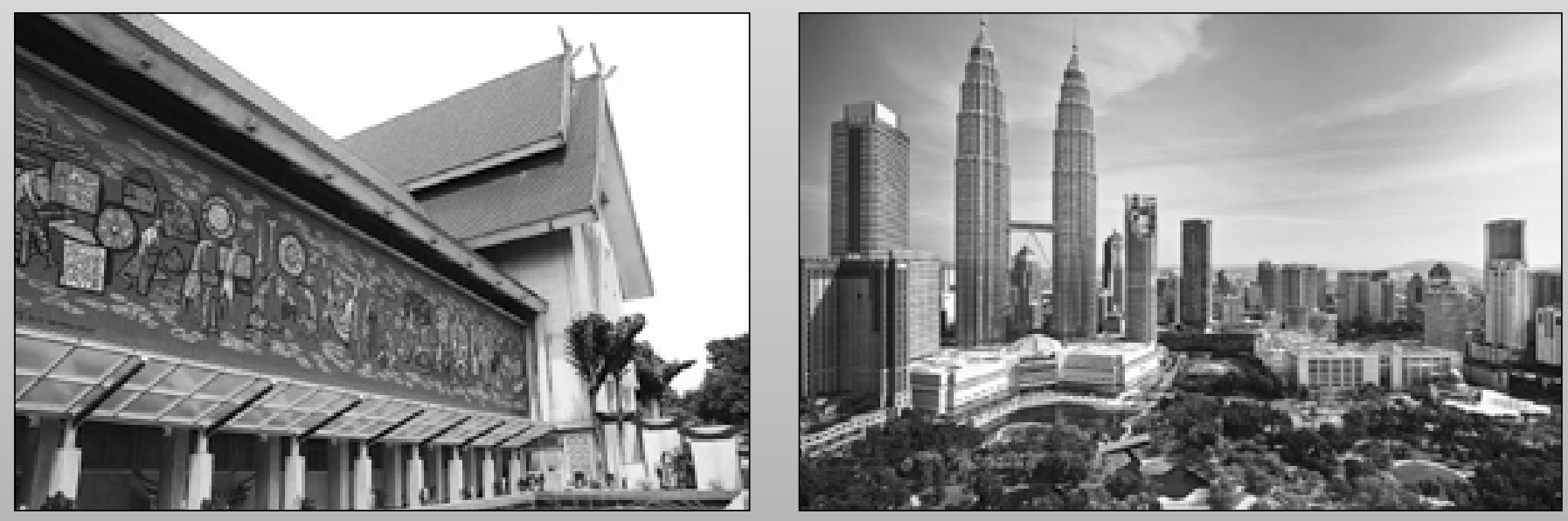
$35^{\text {th }}$

\section{ESPEN}

Congress

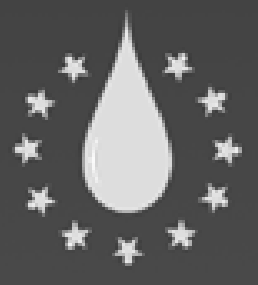

THE EUROPEAN

SOCIETY FOR

CLINICAL

NUTRITION AND

METABOLISM
ESPEN Congress on Clinical Nutrition \& Metabolism

\section{LEIPZIG, GERMANY \\ 31 August - 3 September 2013}

\section{DATE}

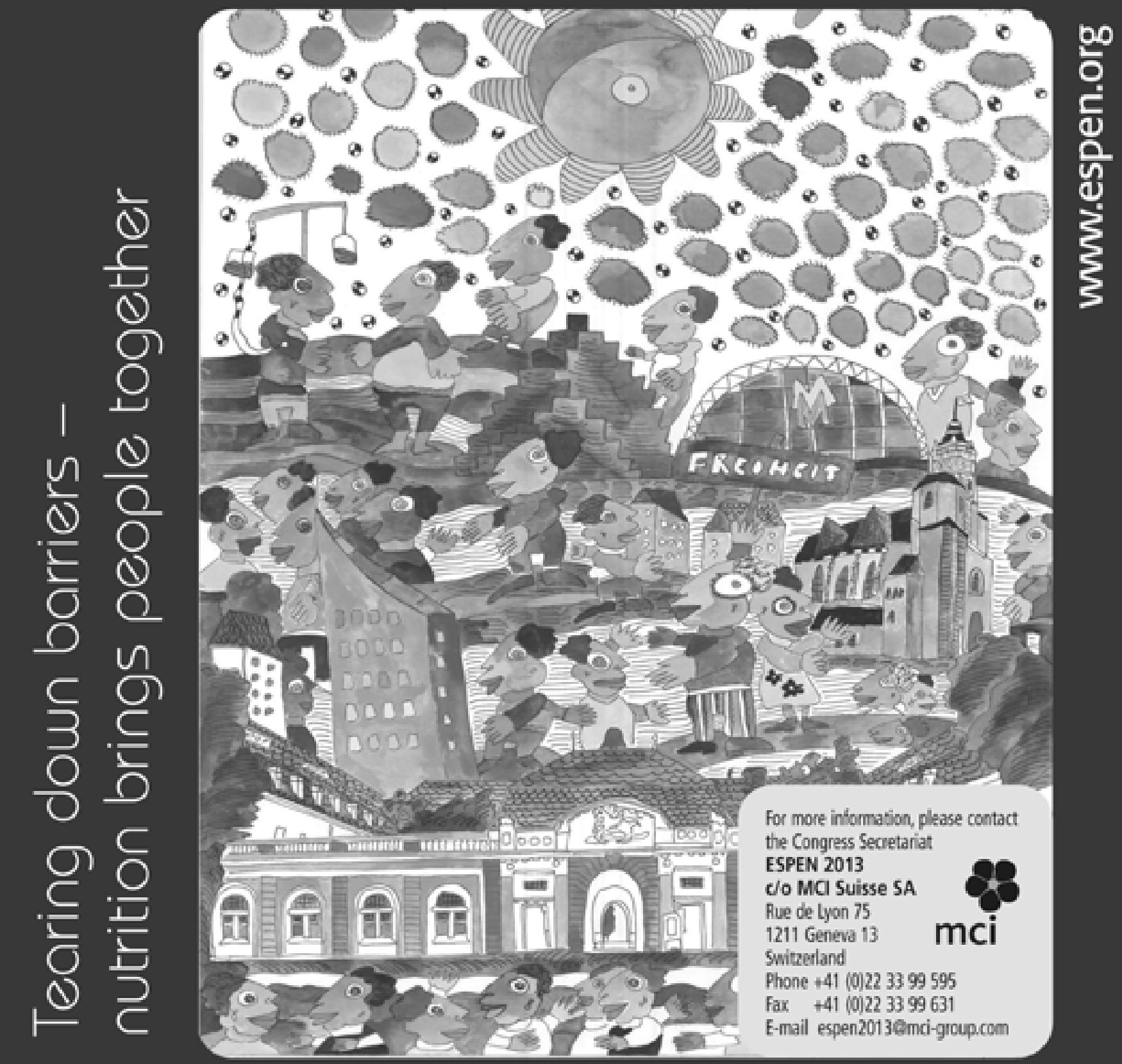




\section{IUNS $2^{\text {th }}$ International Congress of Nutrition}

GRANADA (SPAIN) SEPTEMBER 15-20, 2013 "Joining Cultures Through Nutrition"

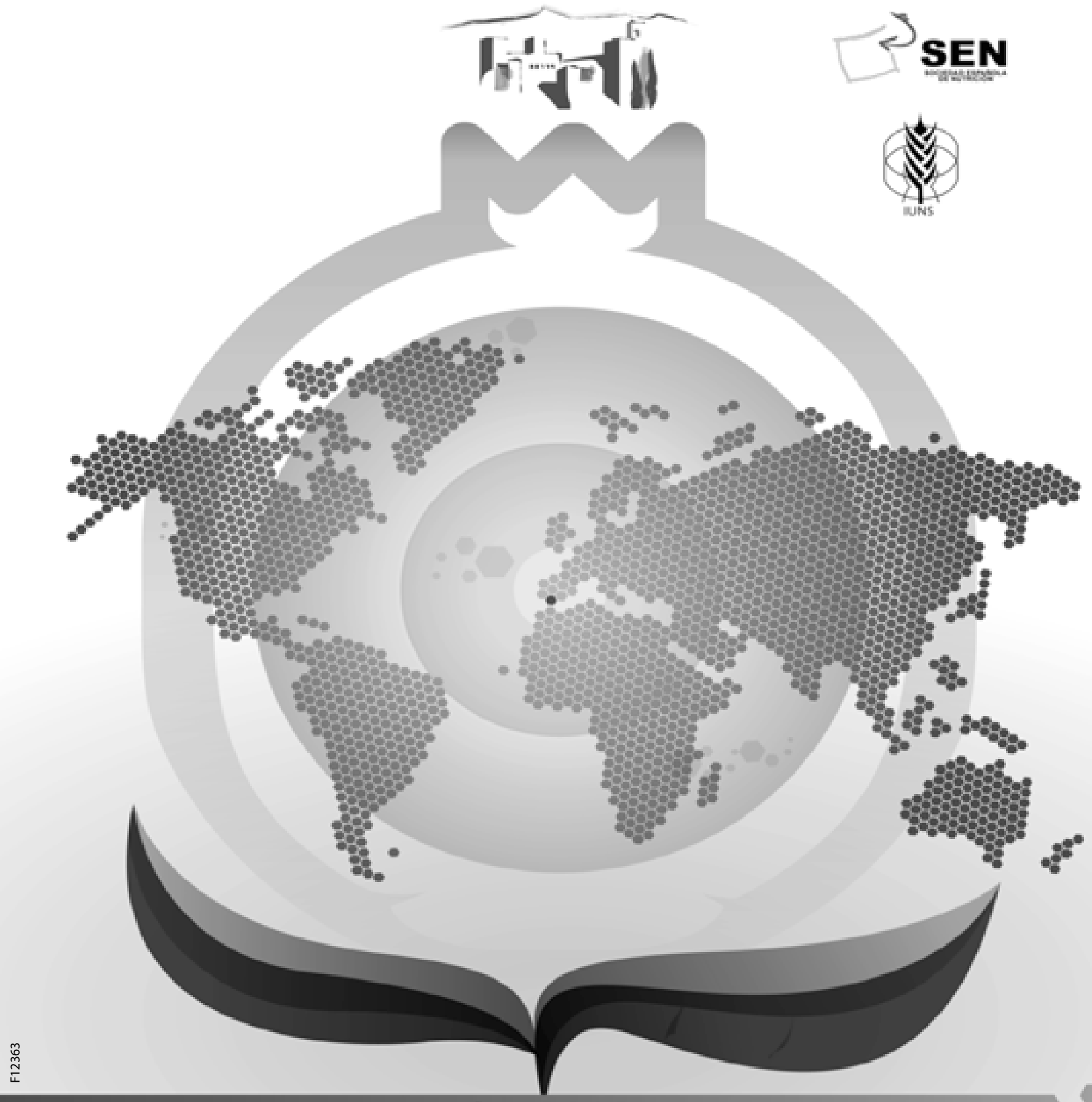

www.icn2013.com

Technical Secretariat:

VIAJES GIBERIA
Viajes Iberia Congresos

Edif. Orizonia - C/ Plaça d' Europa, 17 - $191^{\text {st }}$ Floor 08908 Hospitalet de Líobregat - Barcelona - Spain T. +34935101005 - F. +34935101009 e-mail: icn2013@viajesiberia.com 


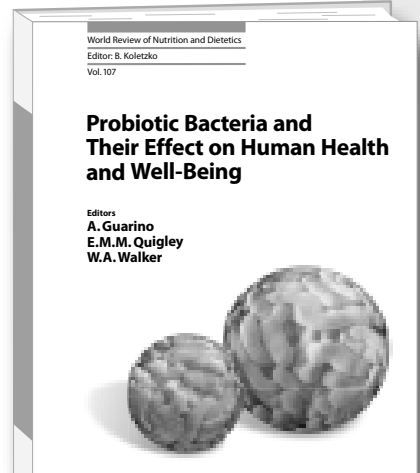

KARGER

\section{Probiotic Bacteria and Their Effect on Human Health and Well-Being}

\author{
Editors \\ Alfredo Guarino \\ Eamonn M.M. Quigley \\ W. Allan Walker
}

Probiotic Bacteria and Their Effect on Human Health and Well-Being

Editors: Guarino, A. (Naples):

Quigley, E.M.M. (Cork);

Walker, W.A. (Boston, Mass.)

XII + 202 p., 22 fig., 17 tab., 2013

CHF 196.- / EUR 163.- / USD 231.00 (hard cover)

CHF 235.- / EUR 196.- / USD 277.00 (online)

Online version for institutional purchase

EUR price for Germany, USD price for USA only

ISBN 978-3-318-02324-4 (hard cover)

e-ISBN 978-3-318-02325-1

World Review of Nutrition and Dietetics, Vol. 107

Series Editor: Koletzko, B. (Munich)

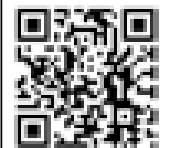

Dear Librarian

I have reviewed this publication and would like to recommend it for our library. Recommended by:

Department:

Date:
Our microflora is an individual personal feature, providing a distinct tag to individuals. However, our intestinal microbiome is strongly affected by genetic, nutritional, and other external factors, and evolves with age. An effect of different microbial patterns on health appears very likely as there seem to be specific changes of intestinal microflora associated with various diseases. Specific microbial tags may thus be used as biomarkers of disease: to diagnose it, to monitor its evolution, and eventually to predict its response to treatment. This scenario opens the opportunity for targeting intestinal microflora using probiotics, both for prevention and treatment of an increasing number of conditions. Probiotic therapy is applied either as an adjunct to other treatments or as primary therapy, and evidence of efficacy is accumulating in several conditions, affecting either the intestine or nonintestinal organs.

This publication provides an update on probiotics directed at physicians, biologists, biotechnologists, and researchers working in the food industry and agriculture, as well as in the environmental and basic sciences.

\section{Contents}

Preface: Guarino, A.; Quigley, E.M.M.; Walker, W.A.

Composition and Modulation of Intestinal Microbiota

- Probiotics: Definition and Taxonomy 10 Years after the

FAO/WHO Guidelines: Morelli, L.

- Intestinal Microbiota Composition in Children:

Buccigrossi, V.; Nicastro, E.; Guarino, A.

- Intestinal Microbiota Composition in Adults:

Robles Alonso, V.; Guarner, $\mathrm{F}$.

- The Intestinal Microbiota and Aging: O'Toole, P.W.; Brigidi, P.

- Shaping Intestinal Bacterial Community by TLR and NLR

Signaling: Kobayashi, K.S.

Functions and Dysfunctions of Intestinal Microflora

- Importance of Early Microbial Colonization for

Intestinal Immune Development: Brandtzaeg, P.
- Effects of the Intestinal Microbiota on Behavior and Brain Biochemistry: Barrett, E.; Dinan, T.G.; Cryan, J.F.; Quigley, E.M.M.; Shanahan, F.; O'Toole, P.W.; Fitzgerald, G.F.; Stanton, C.; Ross, R.P.

- Relationship between Bacterial Colonization of Human Digestive and Respiratory Tract: Lynch, S.v.

\section{Probiotics in the Prevention and Treatment of} Diseases in Adults and Children

- Probiotics in the Prevention and Treatment of

Inflammatory Bowel Diseases in Children: Pigneur, B.; Ruemmele, F.M.

- Functional Gastrointestinal Disorders in Children: Indrio, F.; Riezzo, G.

- Functional Gastrointestinal Disorders in Adults: Quigley, E.M.M.

- Metabolic Syndrome and Obesity in Children: Luoto, R.; ColIado, M.C.; Laitinen, K.; Salminen, S.; Isolauri, E.

- Metabolic Syndrome and Obesity in Adults: Power, S.E.;

Fitzgerald, G.F.; O'Toole, P.W.; Ross, R.P.; Stanton, C.; Quigley, E.M.M.; Murphy, E.F.

\section{Specific Bugs for Specific Diseases}

- Neonatal Necrotizing Enterocolitis: Neu, J.

- Role of Probiotics in Allergies: Berni Canani, R.;

Di Costanzo, M.; Nocerino, R.; Pezzella, V.; Cosenza, L.;

Granata, V.; Leone, L.

- Probiotics in Respiratory Infections: Bruzzese, E.;

Lo Vecchio, A.; Ruberto, E.

Probiotics in Food

- Are Probiotic Effects Dose-Related? Patton, T.J.;

Guandalini, S.

- Safety of Probiotics: Hojsak, l.; Shamir, R.

\section{The Future}

- Age-Related Functional Feeding: A Novel Tool to Improve the Quality of Life: Forssten, S.D.; Röytiö, H.; Ibrahim, F.; Ouwehand, A.C.

- Use of Microbes to Fight Microbes: Hill, C.

-What Is the Future for Therapies Derived from the

Microbiome (Pharmabiotics)? Rijkers, G.T.; Mulder, L.;

Rombouts, F.M.; Akkermans, L.M.A. 


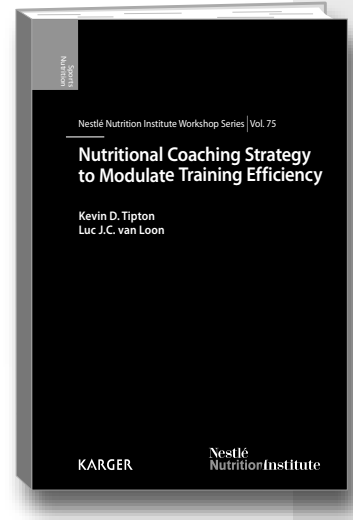

Nutritional Coaching Strategy to Modulate Training Efficiency

Editors: Tipton, K.D. (Stirling):

van Loon, L.J.C. (Maastricht)

XIV + 146 p., 16 fig., 13 tab., 2013

CHF 50.- / EUR 42.- / USD 59.00 (hard cover)

CHF 60.- / EUR 50.- / USD 71.00 (online)

Online version for institutional purchase

Prices subject to change

EUR price for Germany, USD price for USA only

ISBN 978-3-318-02332-9 (hard cover)

e-ISBN 978-3-318-02333-6

Nestlé Nutrition Institute Workshop Series, Vol. 75

Dear Librarian

I have reviewed this publication and

would like to recommend it for our library.

\section{Recommended by:}

Department:
Regular training and adequate nutrition are key factors in modulating exercise performance: optimal performance requires a healthy diet adapted to the specific demands of the individual athlete's training and competition. Research has shown an impact of dietary intervention on the modulation of the skeletal muscle adaptive response to prolonged exercise training. Proper nutritional coaching should therefore not be restricted to the competitive events, but needs to be applied throughout both training and competition, each with its specific requirements regarding nutrient provision. Proper nutritional counseling will thus improve exercise training efficiency and ultimately increase performance capacity. Moreover, dietary counseling to modulate training efficiency is also relevant to the general public and the more frail clinically compromised patient groups. This book provides a solid scientific basis to help the reader define key targets for future interventions and develop new insights into the complex interaction between nutrition and exercise.

\section{Contents}

- Preface

- Foreword

- Contributors

- Nutritional Strategies to Modulate the Adaptive

Response to Endurance Training: Hawley, J.A.

- Practical Considerations for Bicarbonate Loading and Sports Performance: Burke, L.M.

- Influence of Dietary Nitrate Supplementation on

Exercise Tolerance and Performance: Jones, A.M.;

Vanhatalo, A.; Bailey, S.J.

- Nutritional Strategies to Support Adaptation to High-Intensity Interval Training in Team Sports: Gibala, M.J.

- Dietary Strategies to Attenuate Muscle Loss during Recovery from Injury: Tipton, K.D.

- The New Carbohydrate Intake Recommendations: Jeukendrup, $A$.

- Role of Dietary Protein in Post-Exercise Muscle

Reconditioning: van Loon, L.J.C.

- Nutritional Support to Maintain Proper Immune

Status during Intense Training: Gleeson, $\mathbf{M}$.

- Use of $\beta$-Alanine as an Ergogenic Aid: Derave, w.

-Vitamin D Supplementation in Athletes:

Larson-Meyer, E.

-Weight Management in the Performance Athlete: Manore, M.M.

- Concluding Remarks: Nutritional Strategies to Support the Adaptive Response to Prolonged Exercise Training: van Loon, L.J.C.; Tipton, K.D. 


\section{An interdisciplinary journal on human and clinical nutrition}

\section{Annals of \\ Nutrition\& Metabolism}

Editor

B. Koletzko, Munich

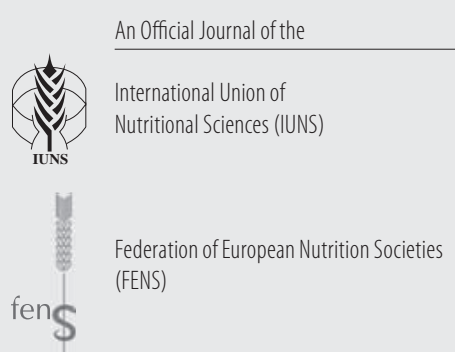

ENA European Nutraceutical Association (ENA)

Deutsche Gesellschaft für Ernährung (DGE)
More information at

\section{www.karger.com/anm}

- Pay-per-View and Subscriber Access to Full Text

- Full Table of Contents

- Full Editorial Board

- Free Abstracts and Selected Articles

- Online Sample Issue

- Submission/Guidelines for Authors

- Subscription Details

- Free Alert Service

- Online Library Recommendation

Annals of Nutrition and Metabolism 2013: Volumes 62,63

4 issues per volume

Language: English

ISSN 0250-6807 (print)

ISSN 1421-9697 (online)

\section{Selected contributions}

- Glycemic Responses of Patients with Type 2 Diabetes to Individual CarbohydrateRich Foods and Mixed Meals: Robert, S.D.; Ismail, A.A.-S. (Kelantan)

- Vitamin D in Relation to Myocardial Structure and Function after Eight Years of Follow-Up: The Hoorn Study: van Ballegooijen, A.J.; Snijder, M.B.; Visser, M.; van den Hurk, K.; Kamp, 0.; Dekker, J.M.; Nijpels, G. (Amsterdam); Stehouwer, C.D.A.; Henry, R.M.A. (Maastricht); Paulus, W.J.; Brouwer, I.A. (Amsterdam)

- Health Effects Related to Low Vitamin D Concentrations: Beyond Bone Metabolism: Moreno, L.A. (Zaragoza); Valtueña, J. (Madrid); Pérez-López, F. (Zaragoza); González-Gross, M. (Madrid/Bonn)

- Upregulation of Hepatic 11-Hydroxysteroid Dehydrogenase-1 Expression in Calcium-Deficient Rats: Takaya, J.; Iharada, A.; Okihana, H.; Kaneko, K. (Moriguchi)

- Diet-Dependent Net Endogenous Acid Load of Vegan Diets in Relation to Food Groups and Bone Health-Related Nutrients: Results from the German Vegan

Study: Ströhle, A. (Hannover); Waldmann, A. (Lübeck); Koschizke, J. (Hannover); Leitzmann, C. (Giessen); Hahn, A. (Hannover)

- Effect of Selenium Supplementation on Glutathione Peroxidase and Catalase Activities in Senescent Cultured Human Fibroblasts: Ghneim, H.K.; Al-Sheikh, Y.A. (Riyadh)

- Role of Nutritional Status in Predicting the Length of Stay in Cancer: A Systematic Review of the Epidemiological Literature: Gupta, D.; Vashi, P.G.; Lammersfeld, C.A.; Braun, D.P. (Zion, III.)

- Effects of Monounsaturated Fatty Acids on Cardiovascular Risk Factors: A Systematic Review and Meta-Analysis: Schwingshackl, L.; Strasser, B.; Hoffmann, G. (Hall in Tirol)
Annals of Nutrition and Metabolism is a leading international peer-reviewed journal for sharing information on human nutrition, metabolism and related fields, covering the broad and multidisciplinary nature of science in nutrition and metabolism. The journal focuses on human nutrition and metabolism and related areas, including experimental studies and basic science that can inform human nutrition science. We welcome manuscripts describing observational and intervention studies as well as basic science reports on the topics of foods, diets and dietary supplements, nutrigenomics and genetics related to metabolism, on energy metabolism, macro- and micronutrients including vitamins and minerals, biofunctional compounds, dietetics, obesity, clinical nutrition, social sciences and health economy as related to nutrition and metabolism and nutrition policy. Laboratory-based science may include descriptions of relevant experimental models. In addition to Original $\mathrm{Pa}$ pers, the journal will publish Review Articles on topical subjects, Systematic Reviews, short Commentaries and Viewpoint articles that may address current controversies, short Meeting Reports, Letters to the Editor, and Announcements/ Society News. The journal will also publish Supplements with proceedings from internationally relevant conferences on nutrition and metabolism. 


\section{Karger Publications in Nutrition}

.

\section{World Review of} Nutrition and Dietetics

www.karger.com/wrund

Series Editor

B. Koletzko, Munich

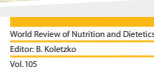

Nutrition in

Intensive Care Medicine:

Beyond Physiology

Edtor
P. Singer

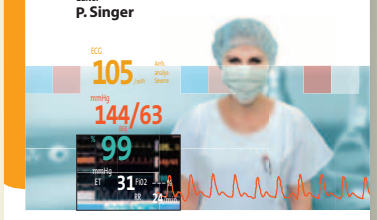

KARGER
Vol. 106

Nutrition and Growth

Vol. 105

Nutrition in Intensive Care Medicine:

Beyond Physiology

Vol. 104

The Vitamin A Story. Lifting the Shadow of Death

Vol. 103

Manual on Vitamin A Deficiency Disorders (VADD)

\section{Annals of Nutrition and Metabolism}

www.karger.com/anm

Current IF: 2.257

B. Koletzko, Munich

\section{Journal of Nutrigenetics and Nutrigenomics}

www.karger.com/jnn

Current IF: 1.143

Editor
J.X. Kang

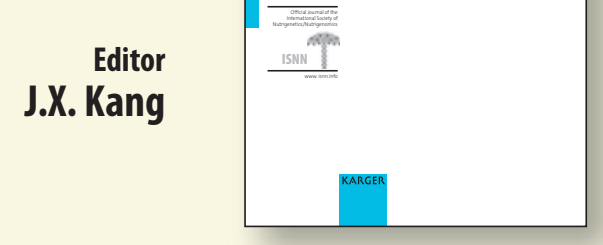

Official Journal of the

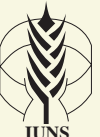

International Union of Nutritional Sciences (IUNS)

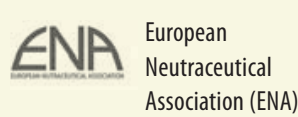

Metabolism

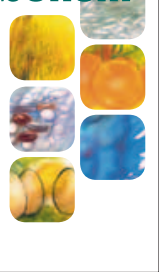

\section{Federation of
European Nutrition
Societies (FENS) \\ Federation of
European Nutrition
Societies (FENS) \\ Federation of
European Nutrition
Societies (FENS) \\ fens}

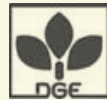

Deutsche Gesellschaft für Ernährung (DGE)
Official Journal of the

International Society of

|IS IN/N| Nutrigenetics/

Nutrigenomics (ISNN)

\section{Nestlé Nutrition Institute Workshop Series}

www.karger.com/nniws

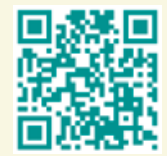

www.karger.com/nutrition

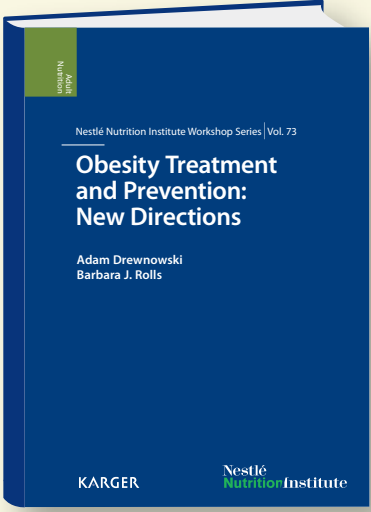

Vol. 73

Obesity Treatment and Prevention: New Directions

Vol.72

Stepping Stones to Living Well with Dysphagia

Vol. 71

Recent Advances in Growth Research:

Nutritional, Molecular and Endocrine Perspectives

Vol.70

Meeting Micronutrient Requirements for Health and Development

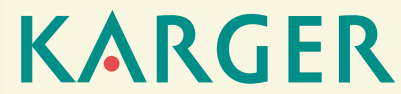

